\title{
STUDI PENGGUNAAN PASIR PANTAI BAKAU SEBAGAI CAMPURAN ASPAL BETON JENIS HOT ROLLED SHEET (HRS)
}

\author{
AKHMAD BESTARI \\ Dosen pada Program Studi Teknik Sipil Universitas Muhammadiyah Palangkaraya
}

\begin{abstract}
ABSTRAK
Kabupaten Seruyan sebagai salah satu kabupaten baru di Provinsi Kalimantan Tengah hingga saat ini masih belum banyak disentuh jaringan transportasi darat. Struktur perkerasan jalan yang lazim di Kalimantan Tengah adalah perkerasan lentur. Perkerasan lentur terdiri atas komposisi agregat kasar, agregat halus, aspal, dan material pengisi.

Pada struktur perkerasan lentur banyak aspek yang harus ditinjau, salah satunya adalah material. Material sering didatangkan dari daerah/tempat lain. Hal ini tentunya tidak menguntungkan dari segi biaya. Sampai saat ini telah banyak penelitian mengenai komposisi campuran yang dilakukan dengan menggunakan berbagai alternatif material. Umumnya penelitian tersebut adalah untuk menguji kemungkinan penggunaan material baru sebagai bahan perkerasan. Selain itu juga terdapat banyak potensi material yang dimanfaatkan salah satunya adalah pasir pantai.

Tujuan dari penelitian ini; pertama, untuk mengetahui apakah pasir Pantai Bakau di Kabupaten Seruyan dapat digunakan sebagai campuran Aspal Beton jenis Hot Rolled Sheet (HRS). Kedua, untuk mengetahui karakteristik campuran aspal beton jenis HRS apabila menggunakan pasir pantai sebagai fine aggregate.

Secara garis besar tahapan kegiatan terbagi menjadi dua, yakni penyelidikan di lapangan dan di laboratorium. Penyelidikan di lapangan merupakan tahap awal yang berupa penentuan lokasi pengambilan sampel dan banyaknya sampel yang diperlukan untuk penelitian. Penyelidikan di laboratorium merupakan tahap lanjutan setelah penyelidikan lapangan yakni pengujian bahan, perencanaan campuran, pembuatan sampel dan pengujian karakteristik HRS dengan Marshall Test.

Dalam mix design pasir pantai diperlakukan dalam empat keadaan berikut: tanpa perendaman, direndam selama 2 hari, 4 hari dan 6 hari dengan masing-masing menggunakan 5 variasi kadar aspal yaitu $6,0 \%, 6,5 \%, 7,0 \%, 7,5 \%$ dan $8,0 \%$.

Hasil penelitian menunjukkan bahwa stabilitas tertinggi diperoleh dari pasir pantai yang direndam selama 6 hari yakni sebesar $846,24 \mathrm{~kg}$. Sementara itu nilai flow, VIM, VFB, dan MQ-nya berturut-turut adalah $3,20 \mathrm{~mm}, 5,64 \%, 74,18 \%$, dan $264,29 \mathrm{~kg} / \mathrm{mm}$. Sedangkan komposisi bahannya (pengisi dan pengikat) adalah sebagai berikut: kadar aspal $7,95 \%$, pasir pantai $=40 \%$, abu batu $=22 \%$, batu pecah $=$ $38 \%$

Saran yang dapat diberikan mengacu pada hasil penelitian ini adalah: untuk dapat digunakan sebagai fine aggregate dalam campuran Hot Rolled Sheet (HRS) kadar garam yang terkandung di dalam pasir pantai bakau harus terlebih dahulu diturunkan melalui perendaman selama minimal 4 hari.
\end{abstract}

Kata-kata kunci: pasir pantai, HRS.

\section{PENDAHULUAN}

Pemekaran di beberapa wilayah kabupaten di Provinsi Kalimantan Tengah secara langsung akan berdampak pada pola pergerakan penduduk, arus barang dan penumpang, tata guna lahan, sarana dan infrastruktur wilayah daerah, yang tentunya berpengaruh pula terhadap transportasi yang ada saat ini. Tersedianya prasarana transportasi darat tentunya akan sangat menunjang segala aktivitas masyarakat dalam berbagai sektor, terutama sektor ekonomi. Karena itu pembangunan jalan menjadi prioritas yang lebih besar. 
Konstruksi badan jalan yang lazim digunakan di Kalimantan Tengah adalah perkerasan lentur. Komposisi campuran dan jenis material yang digunakan dalam perkerasan lentur telah banyak dikembangkan dan diteliti sampai saat ini. Umumnya perkerasan lentur terdiri atas komposisi agregat kasar, agregat halus, aspal, dan material pengisi (filler). Pada struktur perkerasan lentur banyak aspek yang harus ditinjau, salah satunya adalah material. Material kerap didatangkan dari daerah/tempat lain. Hal ini tentunya tidak menguntungkan dari segi waktu dan biaya.

Sampai saat ini telah banyak penelitian mengenai komposisi campuran yang dilakukan dengan menggunakan berbagai alternatif material. Umumnya penelitian tersebut adalah untuk menguji kemungkinan penggunaan material baru sebagai bahan perkerasan. Selain itu juga terdapat banyak potensi material lain yang sangat banyak jumlahnya. Salah satu alternatif yang dapat dimanfaatkan adalah pasir pantai yang banyak terdapat di pesisir-pesisir pantai. Di Kalimantan Tengah khususnya di Kabupaten Seruyan pasir alam yang berasal dari laut jarang sekali digunakan. Penelitian ini dilakukan untuk mendapatkan bahan alternatif disekitar lokasi sebagai material lapis permukaan badan jalan.

Untuk pasir pantai sendiri sebelumnya pernah diteliti oleh Sebayang, S (2002). Dalam penelitian tersebut pasir pantai yang digunakan berasal dari Labuhan Maringgai, Kabupaten Lampung Selatan, terletak di pesisir pantai timur Sumatera yang jaraknya kurang lebih 100 km dari Bandar Lampung. Fokus dari penelitian tersebut adalah pasir pantai untuk campuran Hot Rolled Asphalt (HRA), dengan perlakuan: pasir pantai tanpa perendaman, direndam 1 hari, 2 hari, 3 hari, 4 hari, 5 hari, dan 6 hari. Pada pasir pantai yang direndam selama 6 hari menghasilkan nilai stabilitas $796,74 \mathrm{~kg}$ pada kadar aspal $7,5 \%$, pasir pantai $33,81 \%$, filler $33,42 \%$, dan agregat kasar $22,97 \%$.

\section{Tujuan Penelitian}

Untuk mengetahui apakah pasir pantai, khususnya pasir Pantai Bakau di Kabupaten Seruyan Provinsi Kalimantan Tengah dapat digunakan sebagai fine aggregate dalam campuran Aspal Beton jenis Hot Rolled Sheet (HRS).

\section{Manfaat Penelitian}

a. Penggunaan material alam setempat sebagai bahan konstruksi khususnya untuk lapis permukaan badan jalan.

b. Sebagai bahan informasi dan pertimbangan bagi pihak-pihak yang berkepentingan terkait dengan penggunaan pasir pantai dan perlakuan yang harus diberikan sebelum material tersebut dapat digunakan sebagai campuran HRS.

\section{METODE PENELITIAN}

\section{Pemeriksaan Bahan}

Penelitian dilakukan dengan tahapan kegiatan yang terencana. Secara garis besar tahapan kegiatan terbagi menjadi dua, yakni penyelidikan di lapangan dan di laboratorium. Penyelidikan di lapangan merupakan tahap awal yang berupa penentuan lokasi pengambilan sampel dan banyaknya sampel yang diperlukan untuk penelitian. Sedangkan penyelidikan di laboratorium merupakan tahap lanjutan setelah penyelidikan lapangan, yakni pengujian bahan, perencanaan campuran, pembuatan sampel dan 
pengujian karakteristik HRS dengan Marshall yang dilaksanakan di Laboratorium Jalan Raya Universitas Palangkaraya.

Pengujian bahan dilakukan untuk mengetahui apakah agregat yang digunakan untuk bahan perkerasan memenuhi spesifikasi yang ditetapkan (gradasi, berat jenis dan penyerapan, keausan dan kadar lempung). Disamping itu pengujian bahan juga dimaksudkan untuk memperoleh data yang diperlukan dalam "Perencanaan Campuran".

Agregat (bahan utama) dan yang digunakan harus memenuhi spesifikasi yang disyaratkan Direktorat Jendral Bina Marga (Petunjuk Pelaksanaan Lapis Tipis Aspal Beton Flexible No.12/PT/BNV 1983). Sedangkan metode pengujian agregat mengikuti prosedur yang diterapkan Departemen Pekerjaan Umum 1989 (Metode Pengujian Agregat).
Aspal (bahan pengikat) yang digunakan harus memenuhi persyaratan yang ditetapkan Direktorat Jendral Bina Marga (Petunjuk Pelaksanaan Lapis Tipis Aspal Beton Flexible No. 12/PT/BNV 1983).

\section{Perancangan Campuran}

Tujuan dari "Perancangan Campuran" adalah untuk mendapatkan komposisi yang ideal antara penggabungan bahan batuan (agregat) dan aspal (bahan pengikat) agar menghasilkan suatu campuran perkerasan yang tahan lama dan dapat menahan beban lalu lintas sesuai dengan persyaratan (spesifikasi) yang berlaku. Sifat campuran yang diuji dengan Marshall harus memenuhi persyaratan yang ditetapkan Direktorat Jendral Bina Marga (Petunjuk Pelaksanaan Lapis Tipis Aspal Beton Flexible No. 12/PT/BNV 1983).

\section{Alur Penelitian}

Penelitian mengikuti alur seperti yang diperlihatkan pada Gambar-1. 


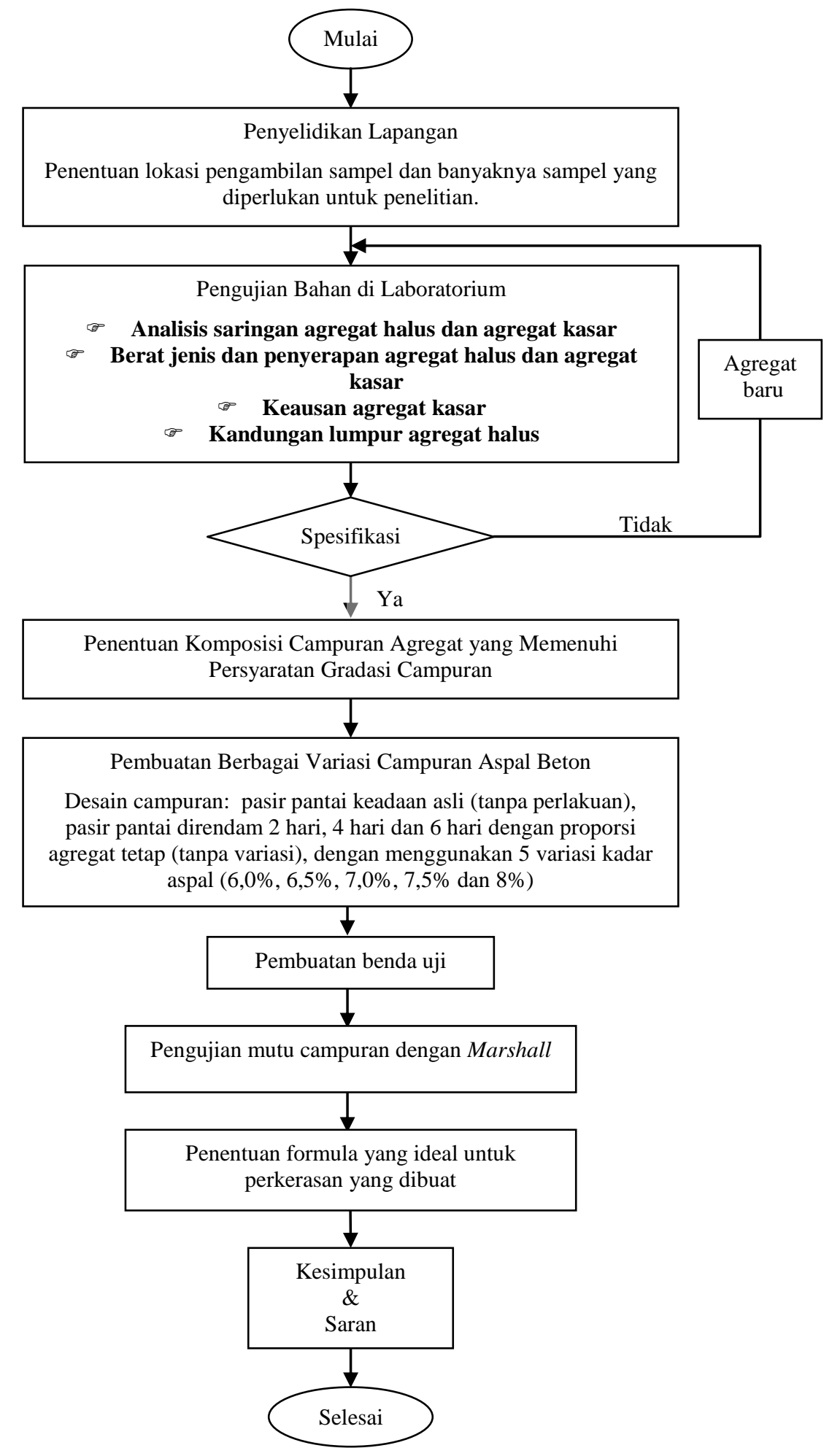

Gambar-1 Diagram alir penelitian 


\section{HASIL DAN PEMBAHASAN}

\section{Hasil Uji Laboratorium}

\section{Agregat}

Pengujian agregat meliputi pemeriksaan gradasi dan pemeriksaan sifat-sifat fisik Hasilnya seperti yang termuat dalam Tabel 1 dan Tabel 2.

Dari hasil pemeriksaan terlihat bahwa agregat yang digunakan untuk bahan campuran HRS memenuhi persyaratan.

Tabel-1 Hasil Pemeriksaan Gradasi

\begin{tabular}{|c|c|c|c|c|}
\hline \hline \multicolumn{2}{|c|}{ Ukuran saringan } & \multicolumn{3}{|c|}{ Persen lolos (\%) } \\
\hline Inch & Mm & $\begin{array}{c}\text { Batu } \\
\text { pecah }\end{array}$ & Abu batu & $\begin{array}{c}\text { Pasir } \\
\text { pantai }\end{array}$ \\
\hline \# 1" & 25,4 & 100,00 & 100,00 & 100,00 \\
\hline$\#$ 3/4" & 19,1 & 100,00 & 100,00 & 100,00 \\
\hline \# 1/2" & 12,7 & 60,14 & 100,00 & 100,00 \\
\hline \#3/8" & 9,52 & 35,31 & 100,00 & 100,00 \\
\hline No. 4 & 4,76 & 5,73 & 99,40 & 100,00 \\
\hline No. 8 & 2,38 & 2,74 & 96,98 & 100,00 \\
\hline No.30 & 0,50 & 1,91 & 30,58 & 89,22 \\
\hline No. 100 & 0,15 & 1,32 & 15,43 & 11,26 \\
\hline No. 200 & 0,075 & 0,74 & 5,84 & 10,38 \\
\hline Pan & 0,000 & 0,00 & 0,00 & 0,00 \\
\hline
\end{tabular}

Tabel-2 Pemeriksaan Sifat-sifat Fisik Agregat

\begin{tabular}{|c|c|c|c|c|c|c|c|c|}
\hline \multirow[b]{2}{*}{ Pemeriksaan } & \multirow{2}{*}{$\begin{array}{c}\text { Batu } \\
\text { pecah }\end{array}$} & \multirow{2}{*}{$\begin{array}{l}\text { Abu } \\
\text { batu }\end{array}$} & \multicolumn{4}{|c|}{ Pasir } & \multirow[b]{2}{*}{ Spesifikasi } & \multirow[b]{2}{*}{ Satuan } \\
\hline & & & \begin{tabular}{|c|}
$\begin{array}{c}\text { Keadaan } \\
\text { Asli }\end{array}$ \\
\end{tabular} & $\begin{array}{l}\text { Perend. } \\
2 \text { hari }\end{array}$ & $\begin{array}{l}\text { Perend. } \\
4 \text { hari }\end{array}$ & $\begin{array}{l}\text { Perend. } \\
6 \text { hari }\end{array}$ & & \\
\hline Berat Jenis Bulk & 2,54 & 3,08 & 2,56 & 2,36 & 2,39 & 2,32 & Min. 2,2 & $\mathrm{gr} / \mathrm{cm}^{3}$ \\
\hline Berat Jenis (SSD) & 2,58 & 3,22 & 2,62 & 2,41 & 2,43 & 2,36 & - & $\mathrm{gr} / \mathrm{cm}^{3}$ \\
\hline Berat Jenis Semu & 2,63 & 3,62 & 2,72 & 2,46 & 2,48 & 2,40 & - & $\mathrm{gr} / \mathrm{cm}^{3}$ \\
\hline Penyerapan & 1,31 & 1,92 & 1,26 & 1,72 & 1,53 & 2,26 & Max. 3 & $\%$ \\
\hline Abrasi & 24,09 & - & - & - & - & - & Max. 40 & $\%$ \\
\hline Sand Equivalent & - & - & 99,19 & - & - & - & Min. 50 & $\%$ \\
\hline
\end{tabular}

\section{Rancangan Campuran Agregat}

Penentuan proporsi tiap-tiap agregat (batu pecah, abu batu, dan pasir pantai) terhadap total agregat dilakukan dengan menggunakan Metode Diagonal berdasarkan data analisa saringan masing-masing agregat, untuk selanjutnya direncanakan komposisi campuran yang tepat agar memenuhi persyaratan gradasi yang ditentukan. Berdasarkan hasil perhitungan dengan Metode Diagonal, diperoleh proporsi terhadap total agregat yang selanjutnya digunakan sebagai acuan untuk mencari proporsi 
terhadap total agregat yang optimal dengan cara coba-coba (trial and error), dengan tetap memperhatikan spesifikasi yang ditentukan sebagai syarat mutlak. Dari perhitungan kombinasi yang dilakukan diketahui bahwa campuran yang memenuhi persyaratan gradasi gabungan (setelah melalui uji Marshall 1) adalah komposisi 2 seperti yang terlihat pada Tabel-3.

Tabel-3 Proporsi Agregat Gabungan yang Memenuhi Syarat (Komposisi 2)

\begin{tabular}{|c|c|c|c|c|c|c|}
\hline \multirow{2}{*}{\multicolumn{2}{|c|}{$\begin{array}{l}\text { Bukaan lobang } \\
\text { saringan }\end{array}$}} & \multicolumn{3}{|c|}{ Persen lolos (\%) } & \multirow{3}{*}{$\begin{array}{c}\text { Total } \\
\text { kombinasi }\end{array}$} & \multirow{3}{*}{ Spesifikas } \\
\hline & & \multirow{2}{*}{$\begin{array}{c}\text { Batu pecah } \\
38 \%\end{array}$} & \multirow{2}{*}{$\begin{array}{c}\text { Abu batu } \\
22 \%\end{array}$} & \multirow{2}{*}{$\begin{array}{c}\text { Pasir } \\
\text { pantai } \\
40 \%\end{array}$} & & \\
\hline Inch & $\mathrm{mm}$ & & & & & \\
\hline \# 1" & 25,4 & 38,00 & 22,00 & 40,00 & 100,00 & 100 \\
\hline$\# 3 / 4 "$ & 19,1 & 38,00 & 22,00 & 40,00 & 100,00 & $97-100$ \\
\hline \# 1/2" & 12,7 & 22,85 & 22,00 & 40,00 & 84,85 & $78-100$ \\
\hline \#3/8" & 9,52 & 13,42 & 22,00 & 40,00 & 75,42 & $60-87$ \\
\hline No. 4 & 4,76 & 2,18 & 21,87 & 40,00 & 64,05 & $55-80$ \\
\hline No. 8 & 2,38 & 1,04 & 21,34 & 40,00 & 62,38 & $52-78$ \\
\hline No.30 & 0,50 & 0,73 & 6,73 & 35,69 & 43,14 & $25-60$ \\
\hline No. 100 & 0,15 & 0,50 & 3,39 & 4,50 & 8,40 & $8-30$ \\
\hline No. 200 & 0,075 & 0,28 & 1,28 & 4,15 & 5,72 & $5-10$ \\
\hline Pan & 0,000 & 0,00 & 0,00 & 0,00 & 0,00 & 0 \\
\hline
\end{tabular}

\section{Marshall 1}

Tabel-4 Hasil Uji Marshall 1 Menggunakan Agregat Gabungan Komposisi 1

\begin{tabular}{|c|c|c|c|c|c|c|}
\hline \hline \multirow{2}{*}{$\begin{array}{c}\text { Kadar } \\
\text { aspal } \\
(\%)\end{array}$} & $\begin{array}{c}\text { Stabilitas } \\
(\mathrm{kg})\end{array}$ & $\begin{array}{c}\text { Flow } \\
(\mathrm{mm})\end{array}$ & $\begin{array}{c}\text { VIM } \\
(\%)\end{array}$ & $\begin{array}{c}\text { VFB } \\
(\%)\end{array}$ & $\begin{array}{c}\mathrm{MQ} \\
(\mathrm{kg} / \mathrm{mm})\end{array}$ & \multirow{2}{*}{ Keterangan } \\
\hline \hline 6,00 & 1071,96 & 3,97 & 6,69 & 65,89 & 270,08 & $\begin{array}{c}\text { Tidak } \\
\text { memenuhi }\end{array}$ \\
\hline 6,50 & 640,09 & 3,50 & 6,14 & 69,51 & 182,77 & $\begin{array}{c}\text { Tidak } \\
\text { memenuhi }\end{array}$ \\
\hline 7,00 & 435,44 & 3,37 & 6,42 & 69,91 & 129,26 & $\begin{array}{c}\text { Tidak } \\
\text { memenuhi }\end{array}$ \\
\hline 7,50 & 202,17 & 3,03 & 6,44 & 71,14 & 66,61 & $\begin{array}{c}\text { Tidak } \\
\text { memenuhi }\end{array}$ \\
\hline 8,00 & 223,56 & 3,23 & 5,49 & 75,57 & 69,10 & $\begin{array}{c}\text { Tidak } \\
\text { memenuhi }\end{array}$ \\
\hline $\begin{array}{c}\text { Spec. } \\
\rightarrow\end{array}$ & Min. 800 & Min. 3 & $3-6$ & Min. 68 & $\begin{array}{c}\text { Min. } \\
250\end{array}$ & \\
\hline
\end{tabular}


Tabel-5 Hasil Uji Marshall 1 Menggunakan Agregat Gabungan Komposisi 2

\begin{tabular}{|c|c|c|c|c|c|c|}
\hline \hline \multirow{2}{*}{$\begin{array}{c}\text { Kadar } \\
\text { aspal } \\
(\%)\end{array}$} & \begin{tabular}{c}
$|c|$ \\
\cline { 2 - 5 } \\
$(\mathrm{Kg})$
\end{tabular} & $\begin{array}{c}\text { Flowilitas } \\
(\mathrm{mm})\end{array}$ & $\begin{array}{c}\text { VIM } \\
(\%)\end{array}$ & $\begin{array}{c}\text { VFB } \\
(\%)\end{array}$ & $\begin{array}{c}\mathrm{MQ} \\
(\mathrm{kg} / \mathrm{mm})\end{array}$ & \multirow{2}{*}{ Keterangan } \\
\hline \hline 6,00 & 326,39 & 3,20 & 3,76 & 77,63 & 101,93 & $\begin{array}{c}\text { Tidak } \\
\text { memenuhi }\end{array}$ \\
\hline 6,50 & 302,51 & 3,13 & 3,22 & 81,37 & 96,49 & $\begin{array}{c}\text { Tidak } \\
\text { memenuhi }\end{array}$ \\
\hline 7,00 & 424,16 & 3,17 & 4,06 & 78,63 & 133,86 & $\begin{array}{c}\text { Tidak } \\
\text { memenuhi }\end{array}$ \\
\hline 7,50 & 518,53 & 3,07 & 4,09 & 79,52 & 168,98 & $\begin{array}{c}\text { Tidak } \\
\text { memenuhi }\end{array}$ \\
\hline 8,00 & 870,04 & 3,17 & 4,14 & 80,26 & 274,58 & Memenuhi \\
\hline $\begin{array}{c}\text { Spec. } \\
\rightarrow\end{array}$ & Min. 800 & Min. 3 & $3-6$ & Min. 68 & $\begin{array}{c}\text { Min. } \\
250\end{array}$ & \\
\hline
\end{tabular}

Tabel-6 Hasil Uji Marshall 1 Menggunakan Agregat Gabungan Komposisi 3

\begin{tabular}{|c|c|c|c|c|c|c|}
\hline \hline \multirow{2}{*}{$\begin{array}{c}\text { Kadar } \\
\text { aspal } \\
(\%)\end{array}$} & $\begin{array}{c}\text { Stabilitas } \\
(\mathrm{kg})\end{array}$ & $\begin{array}{c}\text { Flow } \\
(\mathrm{mm})\end{array}$ & $\begin{array}{c}\mathrm{VIM} \\
(\%)\end{array}$ & $\begin{array}{c}\mathrm{VFB} \\
(\%)\end{array}$ & $\begin{array}{c}\mathrm{MQ} \\
(\mathrm{kg} / \mathrm{mm})\end{array}$ & \multirow{2}{\text{Keterangan}}{} \\
\hline \hline 6,00 & 778,41 & 3,57 & 6,29 & 67,57 & 218,11 & $\begin{array}{c}\text { Tidak } \\
\text { memenuhi }\end{array}$ \\
\hline 6,50 & 709,50 & 3,43 & 6,39 & 68,70 & 206,52 & $\begin{array}{c}\text { Tidak } \\
\text { memenuhi }\end{array}$ \\
\hline 7,00 & 988,96 & 3,23 & 6,84 & 68,58 & 305,67 & $\begin{array}{c}\text { Tidak } \\
\text { memenuhi }\end{array}$ \\
\hline 7,50 & 853,79 & 3,17 & 6,46 & 71,18 & 269,45 & $\begin{array}{c}\text { Tidak } \\
\text { memenuhi }\end{array}$ \\
\hline 8,00 & 941,36 & 3,03 & 6,48 & 72,26 & 310,15 & $\begin{array}{c}\text { Tidak } \\
\text { memenuhi }\end{array}$ \\
\hline $\begin{array}{c}\text { Spec. } \\
\rightarrow\end{array}$ & Min. 800 & Min. 3 & $3-6$ & Min. 68 & $\begin{array}{c}\text { Min. } \\
250\end{array}$ & \\
\hline
\end{tabular}

\section{Marshall 2}

Uji Marshall 2 dilakukan berdasarkan nilai Kadar Aspal Optimum (KOA) yang diperoleh dari hasil uji Marshall 1 dengan menggunakan agregat gabungan yang memenuhi syarat, yaitu komposisi 2. Hasilnya dirangkum dalam Tabel-7. 
Tabel-7 Hasil Uji Marshall 2 Menggunakan (KAO = 7,95\%)

\begin{tabular}{|c|c|c|c|c|c|c|}
\hline \multirow{2}{*}{$\begin{array}{l}\text { Perlakuan } \\
\text { terhadap pasir }\end{array}$} & \multicolumn{5}{|c|}{ Marshall Properties } & \multirow[b]{2}{*}{ Keterangan } \\
\hline & $\begin{array}{l}\text { Stabilitas } \\
(\mathrm{kg})\end{array}$ & $\begin{array}{l}\text { Flow } \\
(\mathrm{mm})\end{array}$ & $\begin{array}{l}\text { VIM } \\
(\%)\end{array}$ & $\begin{array}{l}\text { VFB } \\
(\%)\end{array}$ & $\begin{array}{c}\mathrm{MQ} \\
(\mathrm{kg} / \mathrm{mm})\end{array}$ & \\
\hline $\begin{array}{l}\text { Tanpa } \\
\text { rendaman }\end{array}$ & 805,53 & 3,37 & 5,98 & 73,29 & 239,12 & $\begin{array}{c}\text { Tidak } \\
\text { memenuhi }\end{array}$ \\
\hline $\begin{array}{l}\text { Rendaman } 2 \\
\text { hari }\end{array}$ & 812,41 & 3,37 & 5,85 & 73,58 & 241,16 & $\begin{array}{c}\text { Tidak } \\
\text { memenuhi }\end{array}$ \\
\hline $\begin{array}{ll}\text { Rendaman } 4 \\
\text { hari }\end{array}$ & 825,93 & 3,20 & 5,79 & 73,89 & 257,94 & Memenuhi \\
\hline $\begin{array}{ll}\text { Rendaman } & 6 \\
\text { hari } & \end{array}$ & 846,24 & 3,20 & 5,64 & 74,18 & 264,29 & Memenuhi \\
\hline Spec. $\rightarrow$ & Min. 800 & Min. 3 & $3-6$ & Min. 68 & $\begin{array}{l}\text { Min. } \\
250\end{array}$ & \\
\hline
\end{tabular}

\section{Pembahasan}

\section{Stabilitas}

Stabilitas adalah kemampuan suatu campuran aspal untuk menerima beban sampai terjadi kelelehan plastik, besarnya nilai stabilitas dinyatakan dalam $\mathrm{kg}$. Nilai stabilitas akan terus meningkat dengan berkurangnya kadar garam pada pasir. Hal ini dikarenakan dengan berkurangnya garam yang terdapat pada pori-pori pasir maka aspal akan meresap dengan lebih baik dan dapat mengikat agregat dengan lebih sempurna sehingga menghasilkan nilai stabilitas yang tinggi. Stabilitas tertinggi diperoleh dari pasir pantai rendaman 6 hari sebesar $846,24 \mathrm{~kg}$. Sementara untuk pasir tanpa rendaman (keadaan asli) nilai stabilitasnya adalah yang terendah, namun masih memenuhi spesifikasi yang disyaratkan.

\section{Pelelehan (Flow)}

Kelelehan plastis (flow) adalah kemampuan perkerasan untuk menerima lendutan (deflection) akibat beban lalu lintas yang tinggi dan tidak boleh terjadi retak-retak pada lapisan permukaan. Nilai kelelahan juga merupakan indikator kelenturan dari lapisan perkerasan. Spesifikasi nilai flow HRS adalah minimum $3 \mathrm{~mm}$. Bila nilai flow kurang dari $3 \mathrm{~mm}$ maka akan mudah mengalami retak karena perkerasan bersifat kaku. Nilai flow akan meningkat seiring dengan meningkatnya kadar garam pada pasir. Hal ini disebabkan karena garam adalah senyawa yang dapat larut dalam zat cair (aspal) sehingga tingkat keelastisan atau fleksibiltias campuran akan semakin berkurang jika pasir banyak terkandung garam.

\section{Hasil Bagi Marshall (Quotient Marshal)}

Hasil Bagi Marshall (QM) adalah hasil bagi antara nilai stabilitas dengan nilai kelelahan (flow). Nilai QM yang disyaratkan adalah minimum $250 \mathrm{~kg} / \mathrm{mm}$. Dari hasil perhitungan terlihat bahwa nilai QM akan semakin meningkat seiring dengan penurunan kadar garam pada pasir.

\section{Rongga Udara dalam Campuran (VIM)}

Rongga udara dalam campuran (void in mixture) merupakan indikator terhadap ketahanan campuran (durabilitas). Rongga udara yang cukup akan memberikan kesempatan untuk pemadatan tambahan yang timbul akibat beban lalu lintas yang berulang-ulang pada masa layanan jalan. 
Nilai rongga udara dalam campuran yang di syaratkan untuk campuran aspal beton jenis HRS adalah $3 \%$ sampai dengan $6 \%$. Hasil perhitungan menunjukkan bahwa nilai rongga udara dalam campuran akan semakin kecil seiring dengan penurunan kadar garam pada pasir sehingga aspal akan lebih banyak meresap kedalam rongga agregat halus dan menyebabkan rongga udara pada campuran bertambah besar.

\section{Rongga Berisi Aspal (VFB)}

Persentase rongga terisi aspal (void in fled bitumen) adalah persentase rongga antara butiran agregat kurang mencukupi. Sehingga butiran agregat mudah lepas dan akan mempengaruhi ketahanan (durabilitas) campuran. Sedangkan jika nilai rongga terisi aspal terlalu besar mengindikasikan bahwa pada campuran tersebut terjadi aspal naik kepermukaan lapisan (bleeding). Persyaratan nilai rongga udara terisi aspal untuk campuran aspal beton jenis HRS adalah $\min 68 \%$. Dari hasil perhitungan terlihat bahwa nilai rongga terisi aspal akan meningkat jika kadar garam pada pasir semakin menurun. Ini terjadi karena garam yang terdapat pasir mengurangi pengikatan agregat oleh aspal.

\section{KESIMPULAN DAN SARAN}

Dari pembahasan yang telah dipaparkan pada bab sebelumnya, dapat ditarik kesimpulan sebagai berikut:

1. Secara umum pasir Pantai Bakau Kabupaten Seruyan memberikan nilai properties Marshall (stability, flow, VIM, VFB, QM) yang memenuhi persyaratan yang ditetapkan. Namun untuk pasir dalam keadaan asli dan yang diberi perlakuan dengan perendaman 2 hari nilai QM-nya berada dibawah angka yang disyaratkan sehingga tidak dapat digunakan sebagai agregat halus dalam campuran HRS.

2. Stabilitas tertinggi diperoleh dari pasir pantai yang direndam selama 6 hari yakni sebesar $846,24 \mathrm{~kg}$. Sementara itu nilai flow, VIM, VFB, MQ-nya berturut-turut adalah $3,20 \mathrm{~mm}$, $5,64 \%, 74,18 \%, 264,29 \mathrm{~kg} / \mathrm{mm}$. Sedangkan komposisi bahannya (pengisi dan pengikat) adalah sebagai berikut: kadar aspal $=7,95 \%$, pasir pantai $=40 \%$, abu batu $=22 \%$, batu pecah $=38 \%$

Saran-saran yang dapat diberikan mengacu pada hasil penelitian ini adalah: untuk dapat digunakan sebagai fine aggregate dalam campuran Aspal Beton jenis Hot Rolled Sheet (HRS) maka kadar garam yang terkandung di dalam pasir pantai bakau terlebih dahulu harus diturunkan melalui perendaman selama minimal 4 hari.

\section{DAFTAR PUSTAKA}

AASHTO (1982), Standart Spesification for Transformation Material and Method for Sampling and Testing, Part 1, "Spesification", 13"Edition, July, 1982.

Departemen Pekerjaan Umum (1989), Metode Pengujian Agregat, Jakarta, Yayasan Penerbit Pekerjaan Umum.

Direktorat Jenderal Bina Marga (1996), Pengujian Bahan Jalan dan Jembatan, Jakarta, Departemen Pekerjaan Umum.

Direktorat Jendral Bina Marga (1983), Petunjuk Pelaksanaan Lapis Tipis Aspal Beton Flexible (Lataston) No. 12/PT/BNV 1983, Jakarta, Departemen Pekerjaan Umum.

Direktorat Jendral Bina Marga (1988), Aspal Campuran Panas Dengan Durabilitas Tinggi, Buku 1: Rencana Campuran Central Quality \& Monitoring Unit (CQCMU), Jakarta, Departemen Pekerjaan Umum. 
Pusat Litbang Jalan dan Jembatan (2007), Spesifikasi Umum Bidang Jalan dan Jembatan, Divisi 6: Perkerasan Beraspal, Jakarta, Departemen Pekerjaan Umum.

Sebayang, S. (2002), Pengaruh Pasir Pantai Terhadap Mutu Campuran Aspal Beton, Penelitian Fakultas Teknik Universitas Lampung.

Sukirman, S. (2003), Beton Aspal Campuran Panas, Bandung, Granit. 